\title{
Water Distribution Network Analysis for Vellore Town Panchayat Using GIS and EPANET
}

\author{
Elangovan. $\mathrm{K}^{1}$ \\ \{ela.civil@psgtech.ac.in\} \\ Professor, Department of Civil Engineering, PSG College of technology, Coimbatore-641004 ${ }^{1}$
}

\begin{abstract}
Water distribution system serves many purposes in addition to the provision of water for the human consumption and hence it is an important component in the development of an area. Due to urbanization, the population of city is increasing drastically and hence the distribution system should be designed in such a way that it should satisfy the consumers demand at adequate pressure. Analysis of water distribution system involves determining the quantities of flow, head loss in various pipes sections and resulting residual pressure. The study area chosen for the project is Vellalore town panchayat of Coimbatore district. The main source of water supply to the area is from Athikadavu. The present distribution system consists of 7 overhead tanks which is inefficient to meet the future demands. The feasibility of increasing the tank in the study area was identified. New tank location is placed foreseeing the future population expansion of the area. The topographic map of the study area is obtained from Google earth. Spatially bound network model for the newly determined capacity is created by using polyline theme in ArcView GIS software. The network created is based on the road pattern of the area. The network model generated is georeferenced to real world features. The georeferenced network from ArcView GIS is imported into the EPANET by using interchange tool. Nodal elevation is taken from digital elevation map. Manual calculation is carried out for determining the effective size of the pipes using HazenWilliam's nomogram. Elevation and demand as a nodal input and pipe sizes and length as link input hydraulic simulation of the model is carried out using EPANET software. The result from the EPANET shows that the pressure at each node is within the limits.
\end{abstract}

Keywords: Water Distribution, Population, Capacity, ArcView GIS, EPANET, Network.

\section{Introduction}

Water supply network plays a vital role in infrastructure projects of the city. The basic function of water supply system is to transport water from treatment facility to the consumer. The distribution system also provides storage facilities and required flow and pressure for fire protection. The major issues prevailing in the distribution system is distributing water with adequate pressure and at the same time quality of water arriving at the consumer ends should be within the prescribed limits. GIS is a tool that collect, stores, analyze and display geographically referenced data. In this project GIS is used as a mapping tool for distribution utilities and it also offers extensive functions such as spatial analysis and data management. Water supply system based on GIS, makes the process easy, efficiency and exact. Design and analysis of water distribution system is a complex process and involves various steps and 
consumption of time. The work performed by Arunkumar and Nethaji mariappan(2011), highlights the process involved in the design of water supply system for the area named Kathgarh.

\section{Objective}

The objective of the project is

1. To develop water distribution network line for the future demand using ArcView GIS for the study area.

2. To determine the effective sizes of the pipes using Hazen-Williams formula by manual method

3. To determine the various parameters such as head, velocity and pressure of water distribution network using EPANET.

\section{Study area}

The study area selected is vellalore town panchayat is shown in fig 1 . It is located 12 $\mathrm{Km}$ towards south from district headquarters Coimbatore. Its location is at 77o01'39' $\mathrm{E}$ and $10058^{\prime} 40^{\prime \prime}$. It has a population of 24,872 as per census of 2011. It comes under Madukkarai taluk. It has an area of about $16.64 \mathrm{Km} 2$ with 15 wards. The main source of water to the study area is from Athikadavu.

\section{Methodology}

The methodology adopted for this project is forecasting of population for the design period using suitable method. The water demand for various purposes such as industrial, commercial and domestic purposes are known and average percapita consumption of water is calculated as per the codal provisions. The capacity of the reservoir is calculated using manual method. The new network to be proposed for the study area is drawn using polyline theme in ArcView GIS and analysis is carried out using EPANET.

\section{Population Forecasting}

The population forecasting is an important factor in planning an network when the project has to serve the community for the certain design period. The design period for the distribution system is 30 years. The population at the end of the design period can be predicted by using various forecasting methods. Since it is a growing town geometric method is used keeping 2018 as a base year as shown in table 1. 


\section{Water Demand}

The Water demand for the town is divided into various purposes such as domestic, institutional, commercial and industrial use. According to central public Health Environmental Engineering Organization manual, the average water demand, for the town is 1351pcd excluding water loses in pipes which accounts for $15 \%$.

\section{Storage capacity of tank}

The present system is inefficient to cater the future demands since the design period of the system is over. The storage capacity of tank is calculated for forecasted population.The pumping is done for $8 \mathrm{hrs}$ from 5am-9am and 5pm-9pm. The system is designed for continuous supply of water rather than intermittent supply. The design of storage capacity of tank is shown in table 2

$$
\begin{aligned}
\text { Quantity of water estimated } & =33658 * 135 * 1.15 \\
& =5225404 \text { litres }
\end{aligned}
$$

Capacity of tank = maximum of surplus + maximum of deficit

$$
=156800 \text { litres }
$$

\section{ArcView GIS}

ArcView GIS was developed by Environmental System Research Institute (ESRI) which is a geographic information system software product that allow the user to visualize, analyze, query, map and organize geographic information. The extension that will be validated in this test plan and report are spatial analyst, geoprocessing, data query etc. It has high level generic geographic data model for representing spatial information such as features, raster and other spatial types. In this project, ArcView GIS is used to create the network using polyline theme which is shown in fig 2.

\section{Interchange Method}

Interchange method involves batch process approach to interchange data between a GIS and a computer model. In this method, there is no direct link between GIS and model. Both run separately and independently. The GIS database is processed to extract model input parameters which are manually copied into a model input file. Similarly, model output file are manually copied in a GIS as a new spatial layer for representation of map. 


\section{Determination of Pipe size}

The effective sizes of the pipes are calculated by using Hazen-Williams formula by assuming pipe size which involves various trials. This process is cumbersome and time consuming. In order to make the process easy Hazen William's nomogram has been used. In this chart a straight edge is placed in the known values of flow and assumed pipe diameter, the unknown value head loss can be found. The pipe materials used is Cast Iron. The manual calculation carried out is shown in table 3 and table 4 .

Table 1: Population forecasting for vellalore

\begin{tabular}{|c|c|}
\hline Design year & Forecasted population \\
\hline 2028 & 28580 \\
\hline 2038 & 31016 \\
\hline 2048 & 33658 \\
\hline
\end{tabular}

Table 2: Storage capacity of tank

\begin{tabular}{|l|l|l|l|l|l|l|l|}
\hline Time & $\begin{array}{l}\text { Percent of Demand } \\
\text { average } \\
\text { consumption }\end{array}$ & $\begin{array}{l}\text { Cumulative Inflow } \\
\text { demand }\end{array}$ & $\begin{array}{l}\text { Cumulative Deficit } \\
\text { inflow }\end{array}$ & surplus \\
\hline 5am-9am 40 & 2090162 & 2090162 & 2612702 & 2612702 & & 522542 \\
\hline $9 a m-5 p m$ & 30 & 1567621 & 3657783 & - & 2612702 & 1045079 & - \\
\hline $5 p m-9 p m$ & 25 & 1306351 & 4964134 & 2612702 & 5225404 & & 261270 \\
\hline 9pm-5am 5 & 261270 & 5225404 & - & 5225404 & & - \\
\hline
\end{tabular}

Table 3: Manual calculation of pipe size

\begin{tabular}{|c|c|c|c|c|}
\hline $\begin{array}{l}\text { Pipe } \\
\text { section }\end{array}$ & $\begin{array}{l}\text { Population } \\
\text { end node }\end{array}$ & $\begin{array}{l}\text { at Population } \\
\text { start node }\end{array}$ & $\begin{array}{l}\text { at|Total } \\
\text { population }\end{array}$ & $\begin{array}{l}\text { Maximum } \\
\text { demand (lps) }\end{array}$ \\
\hline $\mathrm{qr}$ & 199 & 487 & 686 & 3.33 \\
\hline $\mathrm{pq}$ & 785 & 72 & 857 & 4.15 \\
\hline op & 1000 & 105 & 1105 & 3.36 \\
\hline no & 1689 & 263 & 1952 & 9.47 \\
\hline $\mathrm{mn}$ & 2198 & 605 & 2803 & 13.59 \\
\hline $\operatorname{lm}$ & 2967 & 67 & 3034 & 14.72 \\
\hline $\mathrm{kl}$ & 3121 & 90 & 3211 & 15.57 \\
\hline $\mathrm{jk}$ & 3343 & 42 & 3385 & 16.42 \\
\hline ij & 3465 & 84 & 3549 & 17.21 \\
\hline hi & 4326 & 74 & 4310 & 20.90 \\
\hline gh & 4645 & 83 & 4728 & 22.93 \\
\hline $\mathrm{fg}$ & 4871 & 80 & 4951 & 24.01 \\
\hline ef & 5033 & 78 & 5111 & 24.78 \\
\hline
\end{tabular}




\begin{tabular}{|l|l|l|l|l|}
\hline $\mathrm{de}$ & 5282 & 132 & 5414 & 26.25 \\
\hline $\mathrm{cd}$ & 5608 & 71 & 5679 & 27.54 \\
\hline $\mathrm{bc}$ & 6419 & 88 & 6507 & 31.55 \\
\hline $\mathrm{ab}$ & 6803 & 105 & 6935 & 33.63 \\
\hline o'a & 7234 & 87 & 7321 & 35.51 \\
\hline
\end{tabular}

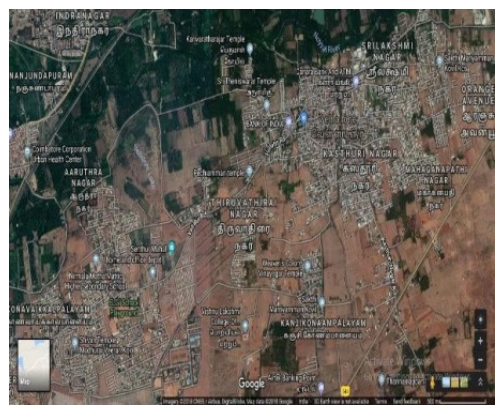

Fig 1: Map of study Area- Vellalore

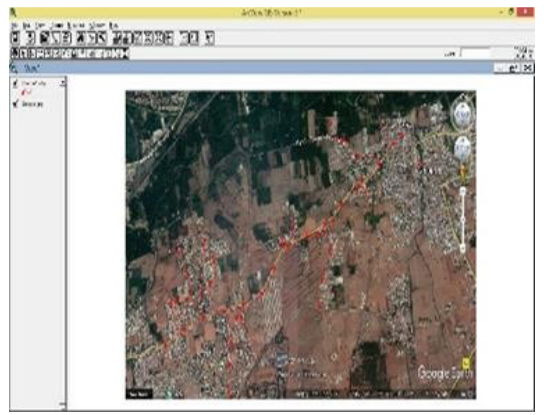

Fig 2: Creation of Water Distribution Network using ArcView

Table 4: calculation of head

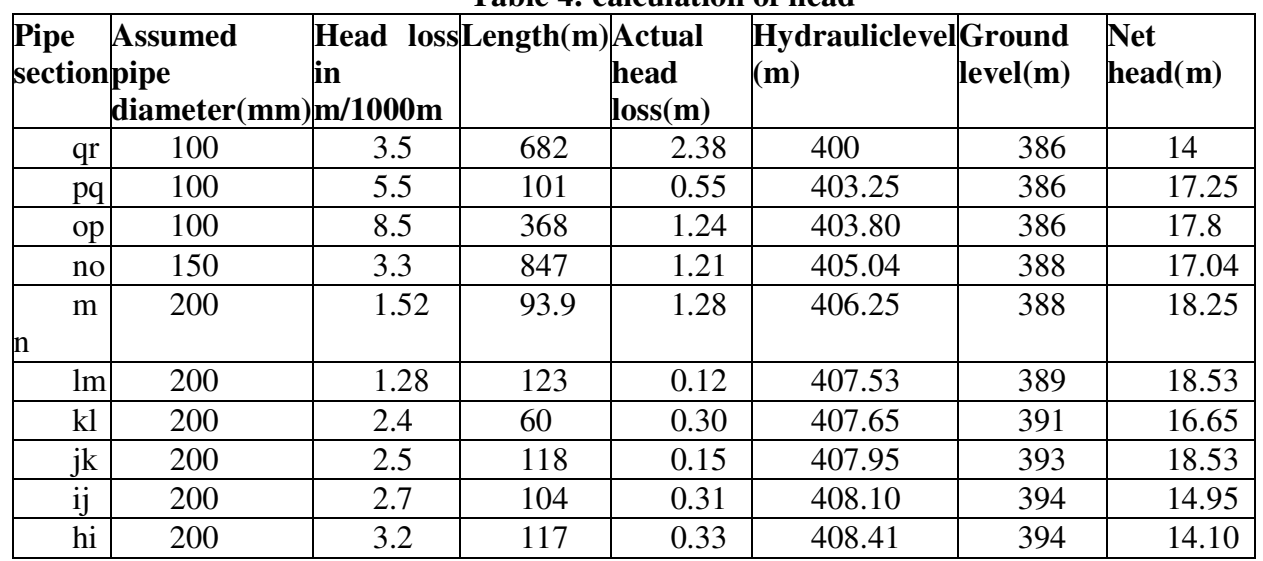




\begin{tabular}{|r|l|l|l|l|l|l|l|}
\hline $\mathrm{gh}$ & 200 & 0.4 & 112 & 0.468 & 408.74 & 397 & 14.41 \\
\hline $\mathrm{fg}$ & 300 & 0.75 & 110 & 0.084 & 409.20 & 397 & 11.74 \\
\hline $\mathrm{ef}$ & 300 & 0.7 & 185 & 0.07 & 409.29 & 397 & 12.20 \\
\hline $\mathrm{de}$ & 300 & 0.8 & 100 & 0.148 & 409.36 & 397 & 12.29 \\
\hline $\mathrm{cd}$ & 300 & 0.75 & 85 & 0.075 & 409.51 & 398 & 11.51 \\
\hline $\mathrm{bc}$ & 300 & 1 & 124 & 0.124 & 409.58 & 400 & 9.58 \\
\hline $\mathrm{ab}$ & 300 & 1.1 & 147 & 0.16 & 409.71 & 401 & 8.71 \\
\hline $\mathrm{o}$ & 300 & 1.4 & 96 & 0.13 & 409.87 & 401 & 8.87 \\
\hline
\end{tabular}

\section{EPANET}

The work carried out by Suraniand Dihora (2015) reports EPANET is a public domain software which model water distribution piping system. EPANET tracks the flow of water in each pipe, the pressure at each node, the height of water in each tank, and the concentration of a chemical species throughout the network during a simulation period. The input parameters given in the nodal points are elevation and base demand. In the pipe sections length, diameter, roughness coefficients are entered manually. The hydraulic simulation of the network is carried out. Kakadiyashital et al, (2017)

\subsection{Input details}

The following table consists of the parameters to be given as an input for the nodal junctions. After the manual entry of inputs single period hydraulic simulation work is carried out for the imported network. The parameters to be given as input is shown in table 5 .

\section{Results and Discussions}

The network drawn consists of 36 nodes, 36 links and 1 tank. The hydraulic simulation of the network is carried out considering the status of the pipes as open and the following results are obtained. The head loss between the start and end nodes of the pipe is computed using Hazen -Williams's formula. The link results are tabulated in the table 7 and nodal results are given the table 6 below. The study area consists mostly of single storey buildings the minimum pressure adopted is $7 \mathrm{~m}$. EPANET results shows that the pressure at each junction point are found to be greater than $7 \mathrm{~m}$ hence the flow can takes place easily. The assumed diameter of each pipe is sufficient enough to withstand the pressure in the entire network. No negative pressure node is identified from the results which show that there is no change in direction of water flow. The entire network has a uniform flow and velocity and there is enough pressure at each node and there is no deficiency in demand. The head loss from simulation results are in correlation with the manually calculated head loss. The results shows that the pressure obtained are satisfy enough to provide water to the study area

Table 5: Input the parameter in to the network

\begin{tabular}{|c|l|l|c|}
\hline NODE & $\begin{array}{l}\text { DEMAND } \\
\text { (lps) }\end{array}$ & $\begin{array}{l}\text { EPANETIN } \\
\text { PUT }\end{array}$ & ELEVATION(m) \\
\hline O' $^{\prime}$ & 35.51 & - & 410 \\
\hline
\end{tabular}




\begin{tabular}{|c|c|c|c|}
\hline $\mathrm{a}$ & 0.42 & 35.09 & 401 \\
\hline 1 & 1.45 & 33.64 & 399 \\
\hline $\mathrm{b}$ & 0.50 & 33.13 & 401 \\
\hline 2 & 1.58 & 31.55 & 404 \\
\hline $\mathrm{c}$ & 0.43 & 31.12 & 400 \\
\hline 3 & 3.59 & 27.53 & 403 \\
\hline $\mathrm{d}$ & 0.34 & 27.19 & 398 \\
\hline 4 & 0.95 & 26.24 & 397 \\
\hline $\mathrm{e}$ & 0.64 & 25.60 & 397 \\
\hline 5 & 0.83 & 24.77 & 394 \\
\hline $\mathrm{f}$ & 0.38 & 24.39 & 397 \\
\hline 6 & 0.40 & 23.99 & 394 \\
\hline $\mathrm{g}$ & 0.38 & 23.61 & 397 \\
\hline 7 & 0.69 & 22.92 & 394 \\
\hline $\mathrm{h}$ & 0.40 & 22.52 & 394 \\
\hline 8 & 1.62 & 22.12 & 393 \\
\hline $\mathrm{i}$ & 0.35 & 20.50 & 394 \\
\hline 9 & 3.33 & 20.14 & 390 \\
\hline $\mathrm{j}$ & 0.41 & 16.81 & 394 \\
\hline 10 & 0.38 & 16.40 & 392 \\
\hline $\mathrm{k}$ & 0.20 & 16.01 & 393 \\
\hline 11 & 0.64 & 15.81 & 390 \\
\hline 1 & 0.44 & 15.17 & 391 \\
\hline 12 & 0.42 & 14.74 & 391 \\
\hline $\mathrm{m}$ & 0.32 & 14.32 & 389 \\
\hline 13 & 0.80 & 14.00 & 388 \\
\hline $\mathrm{n}$ & 2.93 & 13.21 & 388 \\
\hline 14 & 1.19 & 10.28 & 385 \\
\hline 0 & 1.27 & 9.09 & 388 \\
\hline 15 & 2.84 & 7.82 & 384 \\
\hline $\mathrm{p}$ & 0.51 & 4.98 & 386 \\
\hline 16 & 0.69 & 4.47 & 383 \\
\hline$q$ & 0.35 & 3.78 & 386 \\
\hline 17 & 0.48 & 3.43 & 383 \\
\hline $\mathrm{r}$ & 2.36 & 0.97 & 386 \\
\hline 18 & 0.97 & 0.0 & 384 \\
\hline
\end{tabular}

Table 6: Nodal results

\begin{tabular}{|c|c|c|c|}
\hline Node & $\begin{array}{c}\text { Demand } \\
\text { (lps) }\end{array}$ & Head (m) & Pressure (m) \\
\hline a & 0.42 & 419.85 & 18.85 \\
\hline b & 0.51 & 419.65 & 18.65 \\
\hline c & 0.43 & 419.50 & 19.50 \\
\hline d & 0.34 & 419.40 & 21.04 \\
\hline e & 0.64 & 419.24 & 21.24 \\
\hline f & 0.38 & 419.15 & 20.15 \\
\hline
\end{tabular}




\begin{tabular}{|c|c|c|c|}
\hline $\mathrm{g}$ & 0.38 & 419.07 & 20.07 \\
\hline $\mathrm{h}$ & 1.62 & 418.50 & 14.50 \\
\hline $\mathrm{i}$ & 0.36 & 418.07 & 14.07 \\
\hline $\mathrm{j}$ & 0.41 & 417.72 & 13.72 \\
\hline $\mathrm{k}$ & 0.20 & 417.57 & 14.57 \\
\hline 1 & 0.44 & 417.26 & 16.26 \\
\hline $\mathrm{m}$ & 0.32 & 417.06 & 18.06 \\
\hline $\mathrm{n}$ & 2.93 & 415.48 & 17.48 \\
\hline $\mathrm{O}$ & 1.27 & 415.13 & 17.17 \\
\hline $\mathrm{p}$ & 0.51 & 413.69 & 17.69 \\
\hline$q$ & 0.35 & 413.07 & 17.07 \\
\hline $\mathrm{r}$ & 2.36 & 410.32 & 14.32 \\
\hline 1 & 1.45 & 419.49 & 10.49 \\
\hline 2 & 1.58 & 419.19 & 15.19 \\
\hline 3 & 3.59 & 414.68 & 11.68 \\
\hline 4 & 0.95 & 419.29 & 22.21 \\
\hline 5 & 0.83 & 419.17 & 15.17 \\
\hline 6 & 0.40 & 419.14 & 15.14 \\
\hline 7 & 0.69 & 419.03 & 12.0 \\
\hline 8 & 0.35 & 418.47 & 15.47 \\
\hline 9 & 3.33 & 414.18 & 14.18 \\
\hline 10 & 0.39 & 417.72 & 15.72 \\
\hline 11 & 0.64 & 417.53 & 17.53 \\
\hline 12 & 0.42 & 417.25 & 16.25 \\
\hline 13 & 0.80 & 416.99 & 18.99 \\
\hline 14 & 1.19 & 415.27 & 10.27 \\
\hline 15 & 2.84 & 412.67 & 18.67 \\
\hline 16 & 0.69 & 413.65 & 10.65 \\
\hline 17 & 0.48 & 413.06 & 10.06 \\
\hline 18 & 0.97 & 410.20 & 16.02 \\
\hline $\mathrm{O}^{\prime}$ & 35.46 & 420.00 & 10 \\
\hline
\end{tabular}

Table 7: Link results

\begin{tabular}{|c|c|c|c|}
\hline Node & Flow (lps) & Velocity (m/s) & $\begin{array}{c}\text { Unit head } \\
\text { loss (m) }\end{array}$ \\
\hline $\mathrm{a}$ & 35.46 & 0.50 & 1.53 \\
\hline $\mathrm{b}$ & 33.59 & 0.48 & 1.39 \\
\hline $\mathrm{c}$ & 31.50 & 0.45 & 1.23 \\
\hline $\mathrm{d}$ & 27.48 & 0.39 & 0.96 \\
\hline $\mathrm{e}$ & 26.19 & 0.37 & 0.87 \\
\hline $\mathrm{f}$ & 24.72 & 0.35 & 0.79 \\
\hline $\mathrm{g}$ & 23.94 & 0.34 & 0.74 \\
\hline $\mathrm{h}$ & 22.87 & 0.73 & 4.90 \\
\hline $\mathrm{i}$ & 20.90 & 0.67 & 4.15 \\
\hline $\mathrm{j}$ & 17.21 & 0.55 & 2.89 \\
\hline
\end{tabular}




\begin{tabular}{|c|c|l|l|}
\hline $\mathrm{k}$ & 16.41 & 0.52 & 2.65 \\
\hline $\mathrm{l}$ & 15.57 & 0.50 & 2.40 \\
\hline $\mathrm{m}$ & 14.71 & 0.47 & 2.16 \\
\hline $\mathrm{n}$ & 13.59 & 0.43 & 1.87 \\
\hline $\mathrm{o}$ & 9.47 & 0.30 & 0.96 \\
\hline $\mathrm{p}$ & 5.36 & 0.68 & 9.76 \\
\hline $\mathrm{q}$ & 4.16 & 0.53 & 6.10 \\
\hline $\mathrm{r}$ & 3.33 & 0.42 & 4.04 \\
\hline 1 & 1.45 & 0.18 & 0.87 \\
\hline 2 & 1.58 & 0.20 & 1.02 \\
\hline 3 & 3.59 & 0.46 & 4.65 \\
\hline 4 & 0.95 & 0.12 & 0.40 \\
\hline 5 & 0.83 & 0.11 & 0.31 \\
\hline 6 & 0.40 & 0.05 & 0.08 \\
\hline 7 & 0.69 & 0.09 & 0.22 \\
\hline 8 & 0.35 & 0.04 & 0.06 \\
\hline 9 & 3.33 & 0.42 & 4.04 \\
\hline 10 & 0.39 & 0.05 & 0.08 \\
\hline 11 & 0.64 & 0.08 & 0.19 \\
\hline 12 & 0.42 & 0.05 & 0.09 \\
\hline 13 & 0.80 & 0.10 & 0.29 \\
\hline 14 & 1.19 & 0.15 & 0.60 \\
\hline 15 & 2.84 & 0.36 & 3.01 \\
\hline 16 & 0.69 & 0.09 & 0.22 \\
\hline 17 & 0.48 & 0.06 & 0.41 \\
\hline 18 & 0.97 & 0.12 & \\
\hline & & & \\
\hline
\end{tabular}

\section{Conclusion}

Geo referenced network model created using ArcView GIS can be directly interchanged into EPANET input file. This reduces the work of modeling in EPANET and provides more accurate data. The design period of the existing system has been over. Analysis of demand with the collection of preliminary data shows that there is a requirement of additional water supply source for the study area. The feasibility of increasing the number of tanks in the study area was identified. The new tank was proposed at $10^{\circ} 58^{\prime \prime} 03^{\prime} \mathrm{N}$ and $77^{\circ} 0$ " 04 " E and considering the maintenance and cost of tanks, single tank of 3.68 lakh litre was suggested. The new network has been proposed based on the road pattern and this will meet the future demand. The dead end type of distribution system has been adopted placing tank at a higher elevation. Thus the recommendation is made to the existing system for the improvement of study area for the future demands.

\section{References}


[1] Arunkumar .M \&NethajiMariappan V.E (2011), "water demand analysis of municipal water supply using EPANET software", International Journal on Applied Bio-Engineering, volume- 5, pages 919

[2] Brinda. H. Dave, Gargi Raj Para , Ajay Patel,VijaySingha\&ManikH.Kalubarme (2015),"Continuous Water Distribution Network Analysis Using Geo-informatics Technology and EPANET in Gandhinagar City, Gujarat state, India”,International Journal for scientific Research and Development, Volume-6, Pages 308-318

[3] Surani D J \&Dihora GV (2015), "Review on application of GIS in water distribution system planning and designing", InternationalJournal for Scientific Research and Development, Volume3, Pages-186-188

[4] Kakadiyashital, Mavanikrunali, Darshan Mehta \&Vipin Yadav (2016), “Simulation of existing water distribution network by using EPANET", A Case study of Surat city, Global research and Development Journal for Engineering

[5] Nithin.P.Sonaje\&Mandar.G.Joshi (2015), "A review of modelling and application of water distribution network software", International Journal on Technical research and Application, volume-3, page 174-148

[6] M. Tholkapiyan, A.Mohan, Vijayan.D.S , "A survey of recent studieson chlorophyll variation in Indian coastal waters", IOP Conf. Series: Materials Science and Engineering 993 (2020) 012041, doi:10.1088/1757-899X/993/1/012041.

[7] IS 1172-1993 Code for basic requirement for water supply, drainage and sanitation

[8] SP : 35(S\&T)-1987 Hand book on water supply and drainageManual on water supply and treatment by Central Public Health and Environmental Engineering OrganisationEPANET Website http://www.epa.gov/ordntrnt/ORD/NRMR L/wswrd/epanet

[9] Lewis.A.Rossman(September2000) EPANET 2 USERS MANUAL- Water supply and Water Resources Division National Risk Management Research Laboratory Cincinnati OH 45268 EPA/600/R-00/057

[10] S. M. S. S, D. S. Vijayan, M. Anand, M. Ajona, and T. Jarin, " Biodegradation of P-nitro phenol using a novel bacterium Achromobacterdenitrifacians isolated from industrial effluent water ," Water Sci. Technol., vol. 00, no. 0, pp. 1-12, 2021, doi: 10.2166/wst.2021.354

[11] C. Nivetha, D. S. Vijayan, R. Ravishanker et al., Use of Pennywort for nitrogen and phosphate removal from sewage, Materials Today:Proceedings, https://doi.org/10.1016/j.matpr.2020.05.215 